
with The Swedish Institute of International Affairs

\title{
THE TRAGEDY OF AFGHANISTAN
}

The Social, Cultural and Political Impact of the Soviet Invasion

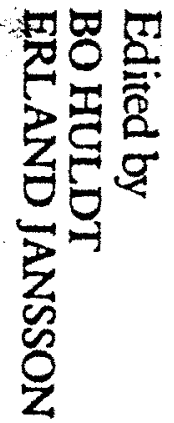

Edited by

BO HULDT

ERLAND JANSSON 


\section{Nationalism}

1. When Muslim ldertity has different Meanings Religion and Politics in Contemporary Alghanistan Asger Christensen

2. Cultural Changes among the Muphing and Muhajerin Louls Dupres?

3 Concepts of Personal. Moral and Social Disouder among Durran Pashiuns in Northern Atghanistan Noncy and Richard Tapper

4. The Kushans. An Afghan Search lor Roois Richard N. Frye

5 Ethnic Factors in Alghanistan's Future Eden Nabr

\section{PART U: Afghan Learning and Education}

6. Past and Present Education in Afghamistan A Problem for the Future Syad a Marrooh

7 Scholars. Saints and Sufis in Moden Algharistan Bo Ulas

8 Modern Political Culture and Traditional Resisiance Olivier Roy

9. Afghan Education during the Wai Batinsman Sali

PART IIt. The War

10 Modernisation from Below: The Alghan Resistance beiween the Fight for Libetation and Social Emancipation Jan.Heeren Grevemever

11 A Locai Perspective on the inciplent Resistance in Alghanistan An Oreser

12 The Alughisn Resistance Arhievemer:s and Problems Mhharmmad Esihaq

13 An Assessment of the New Muiaheddin Alliance Sabohuddin Kushkak

\section{PART IV Ecology}

1.4 Ecologr and the War in Aighanistar Terite Skouland

15. Ellects of the Wat on Agriculture Minimmad Oasim Yusuft

\begin{tabular}{|c|c|}
\hline & 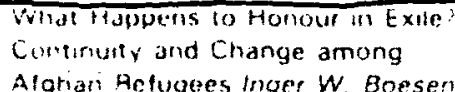 \\
\hline
\end{tabular}

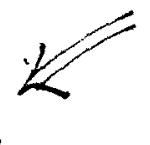

17. Alohis ismads Traphed in Pakistar: Berrit Glatzet

18 The Hele if the VOLAGs Ninfo Haten Dupree 


\title{
MAAT HAPPES TO HONOUR IN RXILE?

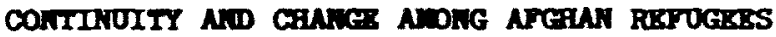

\author{
Inger $W$. Boesen
}

When the Afghan refugees speak about themselves, they do not use the Persian term 'refugees' - panohand but 'travellers', muhajereen. This designation expresses the refugees' desire to return, as well as their hopes that the circumstances that drove them into exile will end in a foreseeable future. But the prospects of returning are still uncertain, and by now many have been refugees for more than six years. New refugees are still crossing the borders of the neighbouring countries of Iran and Pakistan, fleeing from bombed villages, massacres, napalm-burnt crops and ruined irrigation systems, anti-personnel mines, repression by the government, forced conscription, and a famine that is rapidly assuming disastrous proportions.

Today, the proud Afghan people, who have never had to face real colonialisation of their country, constitute the world's largest groups of refugees. Out of approximately 15 million Afghans (in 1978), between 2.8 and 3 million are now refugees in Pakistan,(1) in addition to approximately 2 million in Iran. The best-educated and wealthy Afghans seek refuge in Europe, the USA, and even Australia, whereas those remaining in Pakistan and Iran are predominantly lower middle-class shopkeepers and 'white-collar workers', bazaar craftsmen, as well as the mural population, small farmers and tenants, and village artisans. In particular, the rural population has very limited alternatives to living in the refugee camps, surviving with the help of relief goods. The middle-class, on the other hand, generally try their 
best to survive on their own in the cities, trying to avoid living in the camps, where the 'rural' setting is very alien to their urban background.

Today, approximately every fourth Afghan is a refugee in an alien country. To this comes an estimated number of approximately 1 million Afghans who have been forced to leave their homes in the areas in Afghanistan devastated by war and to take refuge in the mountains or the cities of their own country.

\section{Dot1e}

For refugees all over the world, the problem is the same: how are concepts of identity and self maintained in the refugee situation, when so many of the points of life to which one's concepts of identity have been anchored are lost? Which cultural elements can be maintained in the new surroundings, perhaps providing strength and support for the refugees, and which are changed with the change of environment?

This chapter does not attempt to provide definite answers to all the questions. At the present time, it is only possible to point out trends and raise questions - the answers still lie in the future.

\section{The Afghan refugees in Pakistan}

On one important point, the situation of the Afghan refugees in Pakistan differs from most refugee contexts, at least as far as the Pashto-speaking refugees are concerned. These refugees, the pashtun (or Pakhtun) come from South and East Afghanistan, from provinces adjoining the borders of Pakistan; ethrically, they belong to the same people, living in the border regions of North-West Pakistan, and basically they share the same culture. Superficially, no major conflicts or problems of identity seem to exist, neither in the eyes of the observer nor in those of the Afghans themselves. Nevertheless, at the present time, seven years after the soviet invasion of Afghanistan, and eight years after the arrival of the first refugees, a picture of conflicts and tensions is emerging which may, over time, cause changes in the culture and identity of the Pashtun, both in their ow eyes, and in relation to the Pakistani Pashtun. 
The ideal harmony:

Common language, religion, and cultural system

The Pashto-speaking Afghan refugees and the local population in the host country share three elements fundanental to their society: language, religion, and the Pashtun cultural system, sometimes termed by themselves Pashtunwali ('the Pashtun Way').

obviously, such a shared cultural base is of

wextreme importance to the understanding and coexistence between refugees and the local population. Until recently the co-existence between the two groups has remained relatively free from conflicts, compared to refugee situations in other parts of the world. However, the idyllic image of 'Muslin and Pashtun brotherhood' presented by refugees as well as by locals is in itself part of the culture - harmony and unity of family, agnatic group and tribe, is the ideal - but deep rifts have emerged in the 'brotherhood'.

Religion - Islan

The all-dominating experience shared by Afghan refugees and local Pakistanis is religion. Islam constitutes a spiritual as well as a moral system that offers not only interpretations and perspectives of metaphysical and spiritual questions, establishing a cosmic order to human existence, but also a detalled set of regulations to worldly life, laying down concepts and rules of good and bad, correct and wrong, in almost every aspect of living.

The most important aspect of this religious community, which exists despite variations of interpretazion in different sects and traditions (Shi'a/ Sunni; which is of little importance in the NWFP, the Sufi schools, and different local religious sects), is that the local Pakistanis basically regard the Afghans as their brothers in faith - Muslim brothers - to whom they consequently owe help and hospitality. The common religious values also mean that most Pakistanis share the Afghan view of the war against the communist government and the Soviet invasion forces in Afghanistan as a 'Holy War' - Jihad. In jihad, the Afghans fight not only a territorial war to defend the Afghan homeland, but also an ideological war, against a 
foreign and 'unbelieving' invasion force threatening to destroy the central Islamic values and creed. To lose one's life in Jihad, in defence of Islam, is considered martyrdom, shaheed, and, since a shaheed goes directly to heaven without the usual preliminary ordeals, the religlous aspect of the war provides the Afghan resistance with a powerful ideological motivation.

\section{Language}

The second important cultural element shared by Afghan refugees and the local population in the border areas of Pakistan is the language, Pashto (or Pakhto), which is understood by all pashtun despite local variations of dialect. However, this obviously only holds true for the Pashtun groups among the refugees. Other groups (Persian-speaking Tajiks and Hazaras, as well as Uzbek and Turkoman groups speaking Turkic languages), have great difficulties in communication, and some, mostly living in the cities of the NWFP, make great efforts to learn Pashto.

\section{The Cultare - Good and Bad in the Pashtum Ontrerse}

The third basic common element between refugees and local population is the Pashtun cultural system: an ordered set of values and concepts termed Pashtunwali (Janata and Hassas, 1975). The central elements are the concepts of honour (namus), notions of dishonour (pighur) and shame (sharm), equality (siali) - in principle - held by all Pashtun, coupled with the freedom and autonomy of (male) individuals and agnatic fanily groups and households (azadi); and values pertaining to the types of behaviour defining a person as a 'good' or 'bad' Pashtun (kho or kharap) - something that has to be constantly demonstrated during daily existence, notwithstanding the fact that a person is a Pashtun by descent.

A person who continually manages to demonstrate, through his or her behaviour in different contexts, that he or she fulfils the expectations of Pashtunwall, is said to be a 'good' man or woman, whereas, in the opposite case, he or she will be termed 'bad' (kharap), or 'black' (tor), through behaving 'shame- 
fully'. The terms 'honour' and 'Pashtunwali' are rarely, if ever, used in everyday living. If at all, they may be used in 'theoretical' discussions about Right and wrong, Good and Bad. A 'good' person (of either sex) is often termed aqli, in the Afghan understanding of the Arabic idea 'open to God's Wisdom'.

In the pashtun social universe, like in many Middle Eastern societies with related cultures, central values àre defined basically as focused on men, in relation to 'male' qualities and 'male' activities. Although there exists a strict sexual segregation, 'Institutionalised' in the form of purdah, the seclusion and veiling of women, the 'rules', values, and behavioural norms of the women's universe are largely - but not completely - congruent with those of the male world.

Purdah and honour

Purdah (curtain) is the physical and symbolic isolation of the pashtun women from the outside world, through confinement to the home or screening-off by a veil or all-covering garment (bourga).

The primary function of this seclusion is to prevent any contact or interaction with 'strange' men - i.e. men outside the close family circle - for the purpose of preventing any breach of the married women's sexual fidelity to their husbands, and ensuring the virginal chastity of unmarried girls.

Control of the women is one of the central elements of the basis of $a$ man's and an agnatic family's honour. The honour of the family is embodied in the honour of 1 ts women. The maintenance of family honour requires control as well as protection of women and family, house, and land. House, women, and land are all subsumed under the same concept of honour, namus. The namus of a family household is the embodiment of its socially recognised existence, its autonomy in short its social identity as 'proper Pashtun'. It is the common property(2) and the common cause for all its members to defend against the outer world, that is to say in the Pashtun social universe primarily against other households of similar structure and ideally of equal status. 
As a vital element of the family's control of 'property' in the Pashtun world, women are structurally part of the possessions of the agnatic fanily group - women are perceived as the passive property of men, a view that is, directly and indirectly, widely expressed and shared by Pashtun men. Throughout their lives, women are dependent on men (father, husbands or sons) for their material and social existence; men control land and other productive resources, as well as marriages and lineage affinity (defined by agnatic descent).

Woman is a Witch

May God not Create a House without its Witch'

(Pashtun proverb)

Why this emphasis on the control of women, not only through seclusion, but also through the rights of the husband to use physical means of control, corporal punishment, and even the right to kill his wife in the case of adultery (but, along with this right, also the obligation to kill the lover, in order to 'prove his case' and avoid alienation from the wife's fanily)?

Purdah, which is shared by many other groups throughout and even outside the Middle East, may take different forms in different contexts. I have argued elsewhere (Boesen, 1977), that the practice of purdah can be structurally correlated with interests in private property, primarily land, in a competitive social context, for economic as well as political reasons. Another important function of purdah can be the social delineation of the family group in a socially and/or ethnically mixed context (cf. e.g. Pastner, 1972). The functions of purdah as 'symbolic shelter' of the women and the family against an alien and potentially hostile outer world are particularly pertinent in this context (cf. e.g. Papanek, 1973).

Among the Pashtun, seclusion in purdah is an ideal, closely connected with the concept of family honour, despite the fact that not all groups in society are able to achieve it in practice. The 'necessity' of confining women to the house in order to protect the honour of the family seems to be related to a male view of women as socially immature 
and not fully responsible for their own actions, and consequently not trustworthy of defending the fanily's interests of their own free will. This distrust is structurally most acute in marriages where the wife is an 'outsider', for instance, marriages arranged to confirm an alliance between distant or non-related fanilies, or to confirm the settlement of a feud. (3)

This attitude towards women on the part of the men obviously reflects their awareness that women are not entirely the 'passive property' of the agnatic family, to be subsumed under the control of the men, but that they are able to act against family honour (as well as fanily peace!) - an ambivalence which is expressed in the numerous proverbs and sayings about women as 'witches' (bala) - and corroborated by the popular ideas of romantic love across the boundaries of matrimony, shared by Pashtun of both sexes (Boesen, 1981 and 1983).(4)

\section{Pashtunwall as a cultural system}

The concept of honour is closely related to the notion of equality (siali) of all male Pashtun, since they all belong to the same descent system and thus ultimately can trace their descent through a common ancestor. Honour is thus expressed through the demonstration of equality towards all other Pashtun (cf. Christensen, 1984).

On the other hand, as we have seen, honour is closely connected with man's, or an agnatic group's autonomy based on its ablitty to control and defend the vital elements of the family's social and material existence, embodied in its hoüse, land, women, and fanily honour.

In actual living, this central emphasis on autonomy often encourages the pursuit of individual or family interests vis-a-vis the interests of other family units or even fanily members (e.g. rivalling brothers or agnatic cousins), atriving towards dominance and control.

The conflicts and dilemnas between the values of equality and agnatic solidarity versus the struggle for autonomy, rivalry, and relations of dominance even wthin the agnatic group itself, are integral elements of the Pashtun social universe. 
contains ambiguity, because the maintenance of honour may pose the dilemma of choice between autonomy and agnatic solidarity, both of which are considered important values by the Pakhtun' (Christensen, 1984: 19).

Pashtunwali cannot be understood as a homogeneous and consistent cultural system, but must be seen as a heterogeneous system, based on a set of core values, containing inherent perceptual dilemuas and choices of interpretations of these core values, choices which must be understood in the contexts of specific interests and the process of 'practice'.

This heterogeneous cultural system, with all its built-in ambivalences, open to alternative situational interpretations of its basic values, appears flexible enough to adapt to varying conditions of living. Is it also able to cope with the fundamental changes of a life in exile, deprived of the vital elements of Pashtun identity, Pashtun land?

\section{Reality: Tensions and Conflicts Between Rerugees and Paldstanis}

Competition for resources in ecology and economy

Despite the common value system of the Afghan refugees and the local population in Pakistan, tensions and conflicts, as well as cultural changes, perceived as such by the refugees themselves, have developed.

The roots of this apparent paradox is obviously the new situation where an additional population of between 2.5 and 3 million refugees is crowded into Pakistan, which is itself a developing country with serious problems of unemployment and scarcity of arable land.

The refugees are primarily settled in the NorthWest Frontier Province (NWFP) ( 1.8 million registered refugees), 500,000 in Baluchistan, 100,000 in Punjab (mostly resettled to ease the pressure in the NWFP), and c. 600,000 living unregistered scattered in Pakistan. The registered refugees live in camps of between 10,000 and 100,000 families; the largest camp, with c. 125,000 refugees, being the largest concentration of refugees in the world. Many have brought livestock with them, an estimated total of c. 3 
million head.

There is a growing resentment in the population of Pakistan against the Afghans who have 'invaded' their country, competing heavily with the local population for basic and scarce resources, water, fuel (firewood), and pasture for the livestock. Particularly in the border areas - the so-called 'tribal areas' with local semi-autonomy - and Baluchistan, the ecological balance is and has always been extremely precarious. In many of these areas, the presentce of the additional population has destroyed this balance, causing 'desertification' and consequent soll erosion. The nomads, in particular, who used to cross the border seasonally with their herds, using the pastures temporarily, but now being 'trapped' in one place due to the closing of the border, have contributed considerably to this process. The tensions and the conflicts exist and are continuously being aggravated despite the efforts on the part of UNHCR and a considerable number of relief organisations to alleviate the pressure on ecology through alternative supplies of water and fuel.

\section{Competition for work}

In addition to the competition for the resources of the physical environment, the Afghan refugees const1tute serious competition in the local labour market. The presence of large numbers of refugees seeking employment causes a decrease in local wages, to the detriment and bitterness of the Pakistani population.

A mitigating factor is that many Pakistanis have migrated to the Gulf States in later years for employment in the oll industry (along with many Afghan; refugees). This has caused a gap in the Pakistani economy and provided a niche for the refugees 'at the bottom' of the labour market, offering them the lowest-paid and most despised unskilled jobs such as street vendors, shoe-shiners, construction workers, etc.

However, far from all Afghan refugees constitute a destitute labour force, ready to accept any work at any wage. Quite a few have managed to bring some valuables, which are used as starting capital for establishing themselves in, for instance, bazaar trade 
in the cities as well as in the refugee villages.

One very important and lucrative activity is the illegal trade across the Afghan border by Afghans using Afghan vehtcles, bringing down cherished items to the Pakistani market and the refugees, such as fruit, vegetables, nuts and dried fruit, cloth, timber, etc. Lately, however, this traffic seems to have been lmpeded by the growing control of the border passes, especially the Khyber pass, by Afghan military forces.

other important trade items are the popular Afghan carpets, which are continuously brought out of Afghanistan. Many refugee families of the carpetveaving ethnic groups, especially the Turkoman, continue to produce carpets in Pakistan, on their own, as well as supported by various relief organisations including UNHCR. The carpets are mainly sold in the streets and bazaars in the major cities, but also (the old and expensive carpets) in exclusive carpet boutiques.

Many Afghans are involved in the transport business with trucks or minibuses brought from Afghanistan. To some extent, the trade across the border is in the hands of wealthy nomads, who have invested in modern trucks instead of the traditional canel caravans.

The need for establishing transport services for the refugees, for example in the refugee villages, of which many cover large areas, has also offered a niche for Afghan bus owners.

These trade and transport activities result in serious competition in this sector of the local Pakistani economy. Estimatedly, more than 6,000 Afghan vehicles are now plying the roads on Temporary pegistration licenses, and probably just as many are Afghan-registered. It is no wonder that this is one of the most important causes of resentment towards the Afghans in the Pakistani population.

Another aspect of the entrepreneurial Afghans' economic activities are the shops and bazars flourishing in the refugee camps and the neighbourhoods of the cities where the refugees are concentrated. In the city of Peshawar, the capital of NWFP, it is possible to find almost everything that was to be found in Kabul: Afghan restaurants, tailors, 
jewellery, leather-work, regional food specialities and Afghan music cassettes.

\section{Emergent crisis}

A picture is gradually emerging of a deep rift between the Afghan refugees and the Pakistani population, despite the common culture and their common 'Pashtunness ${ }^{\prime}$.

However, the crisis does not exist only in the relationship between refugees and Pakistanis, but also among the refugees themselves, caused by the very conditions of refugee existence.

The majority of the refugees, small farmers and tenants from the rural areas, have been forced to leave their homes and land, to see it occupled or destroyed by napalm or bulldozers by the invaders. The very foundation of their material and social existence as cultivators - their land - has been swept away.

Because of the Afghans' special situation as refugees in Pakistan, which does not permit permanent asylum but only temporary refuge, even the refugees who could afford it are not able to buy land in Pakistan. The only solution to the problem of getting access to land for cultivation is to arrange, on an individual basis, for the lease or tenancy of land from a local landowner.

In fact, the refugees who were formerly noncultivators, such as tradesmen and skilled artisans who were groups with much more inferior status than farmers in the Pashtun social universe - are now in a better position than the cultivators to earn a living on their own in exile. The majority of the farmers, except for those who have succeeded in finding some unskilled - and low-paid - job, remain idle in the camps, having turned into passive receivers, dependent on aid.

This situation is threatening to the core values of Pashtun self-conception and their identity as Pashtuns, their honour and autonomy.

For the men, the loss of their land means that they have nothing left to do throughout the day except discuss the situation, "What can we do - we have no land - time just passes'. 
Their only answer to this crisis is to return to Afghanistan, as soon as the snow melts in the passes, and fight in the resistance forces, leaving their family behind until next autumn in the care of an old malo-family member such as their father. Many mujahedeen also selze the opportunity to cultivate their land back in Afghanistan, provided the area is peaceful enough.

The women refugees in the camps still have their housework to do: the fanily must be fed, children looked after, clothes such as they are, washed and kept in order, the tent or mud-house (katcha-house) mist be swept, and the few possessions tidied away. The family may own a goat or a few chickens which must be looked after. But even these chores are not enough to fill their days. The women, too, have plenty of time to sit and talk, to grieve their fate, to worry about their husbands or sons fighting in Afghanistan, to moum their dead family members - and to worry about the future.

To the burdens of idleness and dependency come the problems of maintaining the central elements of their culture and moral system and to transfer them to the young generation. Most of the young children are born in Pakistan and have never seen the Afghanistan of which their elders apeak with such longing. The elder generation is deeply worried about their possibilities of bringing up the young ones as 'good Afghans', teaching them the norms and values of the Afghan cultural traditions. Who is there to exercise paternal authority to sons as well as daughters, when the grown-up men are either absent or dead? How will the girls ever have a chance to get properly married when they iare allowed to grow up without the strict hand of a fathes, in a group of women perhaps too preoccupied with their own worries to be able to control the whereabouts of young girls? How can the sons grow into responsible husbands and fathers, learning to work hard to provide for their family, when there is no work and practically no chance of education above the primary level?

one example that shows how the conditions of refugee life may work against the moral values of the Pashtun is the widespread corruption of the distribution of rations in the camps, which may make it 
necessary for a fanily to lie about the real number of family members in order to receive a minimal covering of the family's needs. The elder Afghans themselves shake their heads in worry and despair over the bad example the parents are forced to give to the growing generation. 'We teach them to lie' - which is 'shameful' and socially unacceptable in Afghan culture.

Another serious problem which is also against Pashtun moral values, is the increasing addiction to drugs, mainly anong the young men with no work or educational possibilities. Hashish, heroin and opium are relatively cheap and easy to get in Pakistan. The youngsters who want it get the money mainly through selling part of their rations in the camp bazaars.

Together with the very limited possibilities of secondary education and vocational training, these tendencies towards a weakening of the traditional Afghan values of honesty, independence, industry, and 'soberness', are the most negative prospects for the future of the Pashtun culture, and of Afghanistan, since they affect the young generation most seriously.

\section{Vomen and Purdah}

The functioning and continuity in exile, and also potentials for change, of purdah, are reflected in the situation of the refugee women.

The first thing a Pashtun refugee family will do when installed on its small plot in a refugee camp is to construct some kind of wall or screen of straw mats or sacking around their new home, even if it only consists of a tent. Later, if and when the family can afford it, they may build a proper mud wall and perhaps a house within. As refugees, the Pashtun feel even more obliged to protect and delimit the family and the family house in the strange environment than at home. In the refugee villages, neighbours are often complete strangers, belonging to different subtribes and originating from different regions of Afghanistan, whereas in the home village the social environment was generally familiar, everybody knew everybody, and people were widely united through a common kinship network. Above all, the surrounding Pakistani society is considered as the most serious threat to the Pashtun women and family, despite the 
fact that the local Pakistanis share the Pashtun culture and 1 ts concepts regarding women and purdah.

To the women and girls, this strengthening of purdah means that their possibilities of physical freedom of movement are even more restricted than at home. In their home village, they could leave the house, for example, to visit friends and relatives, and in families which were not rich enough to afford hired labour to fetch water and help in the fields. As refugees, the women's social network also tends to be narrower, since they often live separated from their relatives. The possibilities of school education for the girls are much reduced, at least in comparison with some areas of Pashtun settlement (Eastern Afghanistan), due to different factors in the development of the conflict in Afghanistan, mainly the attempts at forced education of mural women on the part of the socialist regime after the coup in 1978, which has probably meant a serious setback to the Afghan attitudes towards the education of girls, for a long time to come.

The importance attached to purdah in the refugee situation and the problem it causes, such as preventing women from leaving the house to get necessary food supplies in the absence of the male fanily members for prolonged periods, is lliustrated by the following story of a fanily the author of this chapter knows well. (5)

Shera Gul lived with his old mother, one unmarried sister, and his pregnant sister-in-law in a camp near Peshawar. The fanily was very poor, the father was dead back in Afghanistan, and Shera Gul, perhaps 18 years old, had sole responsibility for the funily (his only brother had foined the resistance and was fighting in Afghanistan). For some reason they were unable to obtain rations, not uncommon in the case of 'weak' families like this, consisting of a widow and a son elther too young or not strong-willed enough to insist on their rights. Shera Gul succeeded in finding a job as chowkidar, a watchman, in Peshawar c1ty, in order to support his fanily.

However, because of the nature of the Job, 
he had to stay away for the week, his only day off being Friday. During the whole week, the women were left alone in the compound, not allowed to leave, but also afraid of leaving it to fetch water or buy food. They mostly sustained themselves on supplies brought by Shera Gul on his day off, or by the assistance of neighbours.

Their living quarters were very poor, consisting of a worn-out tent and a small mud house with no roof, since the money for building materials had me out too soon. The narrow compound was surrounded by a low mud wall. The family, the women, as well as Shera Gul, expressed their deep anxiety about thieves and intruders being able to climb the wall, and said they felt insecure. During the week, at his job, Shera Gul was constantly preoccupied with worry about his family, and even collapsed physically several times from the nervous strain, until, faced with the coming of autumn, cold nights and winter rains, he decided to explain the situation to his employers, an international refugee relief organisation, and ask them for help. This resulted in a roof for the house, built by Afghan volunteers employed by the same organisation, on their own initiative and in their spare time, and the employment of an additional watchman to work in shifts with Shera Gul, allowing him an opportunity to stay with his family, which was now endowed with a baby, Shera Gul's niece.

Single women in the refugee camps, widows, or women whose husbands are in Afghanistan, without any male relative to take care of them, have had to assume duties and responsibilities that would normally have been taken over by their husbands or kinship network. These women, 'heads' of 'mother-centred households', have to cope with many difficulties, for instance, in obtaining rations for themselves and their children, because of purdah and the social taboo against a woman negotiating with strange men. On the other hand, it seems that war and refugee life have contributed to a change of roles for these women. In recent years, this category of women has received increased atten- 
tion from several relief agencies, giving, for example, support through special widow programmes, income-earning opportunities, and so on. Future development will show to what extent women, who have taken over the traditionally male role of provider for the fanily, and who perhaps are able to support themgelves on their own income, are ready to give up their social and economic independence in relation to the traditional sex-role pattern, in the event of repatriation.

The daily routine in the camps where most of the men are idle, doing nothing to help the women with the household chores is also slowly changing. It is becoming increasingly common to see a father taking loving care of babies and giving a hand with cooking, cleaning, and fetching water. Whether this change of the traditional division of labour will have lasting effects probably depends on the duration of the exile, and the opportunities for work and education for the young generation.

\section{Pashtamwall in Beile}

What can be concluded about the development of Pashtun culture anong the refugees - which tendencies can be identified against the background of the problems outlined above? And, firgt of all, how can the Pashtun maintain their social identity as Pashtun, their honour, when the basis of the autonony of the Pashtum fanily, control of land, no longer exists?

obviously, anxiety, insecurity, and lack of work are heavy burdens to the refugees. In particular the dependency and its mental consequences are a serious threat to the Pashtun concepts of moral and selfrespect, based as they are on self-reliance and ability to look after one's family. The worry of many Pashtun elders about this threat to their basic moral values reflects a consciousness of this tendency and a will to prevent it, first of all through striving for economic independence. The refugeest efforts to achieve this can be seen in their multitudinous entrepreneurial activities, exploiting different niches in the local Pakistani and refugee economy. However, we have seen that the non-agriculturaliats are much better equipped than the people who used to be highest 
ranked in Pashtun society: the cultivators, whether landowners or tenants. The non-cultivators are in a better position to use their various skills as, for example, tradesmen or specialists. The cultivators have become reduced to the lowest-paid unskilled jobs, if they can get any.

Nevertheless, the refugees seem to have no problems in defining themselves as 'proper Pashtun', at least in relation to the local, Pakistani Pashtun, whom they tend to look down upon even though they belong to the same ethnic group and share the same basic values.

Generally, this seems to be related to the fact that most Pakistani Pashtun are far more integrated in the Pakistani state and urban culture than most of the Afghans from the rural areas ever were. The spreading 'Pakistani' culture, containing many elements of Punjabi culture and even its language, contributes to a gradual weakening of the distinct Pashtum identity in North-West Pakistan. The Afghans tend to look down slightly on the Pakistanis, as 'traitors' to the basic values of Pashtumwali: honour, autonomy, and cultural integrity. On the other hand, the Pakistanis widely consifer the Afghans as 'rural boors'.

Particular causes for the growing rift between Afghans and Pakistanis are the real tensions and conflicts of interests outlined above, which to a growing extent result in open clashes and harassment of the refugees, by the locals, especially in the cities. Other irritants are the corruption of many Pakistani relief administrators regarding the distribution of rations, admission to local hospitals, etc. All these factors contribute to the Afghans' opinion of the Pakistanis as kharap - 'bad' - just as the Pakistanis increasingly consider the Afghans as kharap due to the problems caused by their presence in the local communities.

This mutual distrust is, for example, reflected in the stricter practice of purdah in both groups, each explaining it by the untrustworthiness and 'bad character' of the male members of the other group. The Pakistanis consider the Afghans, especially the young single men in the cities, as a threat to 'their' womenfolk, and complain that they 'have to be more careful now', just as we have seen that the Afghans 
claim the same thing.

But, what about the refugees' conceptions of Pashtun identity and status among themselves?

It seems that the refugees try to solve the problems of honour in relation to autonomy and control of land in various ways:

The family land at home is not lost, it is only temporarily occupied'

The refugees still speak about the land at home as 'their' land; in defining the family's status, the present deprivation still does not seem to be final.

Jihad, the defence of our country,

is our most important namus'

The common cause of defending Afghanistan against the invasion forces and the 'marionette regime' in Kabul is perceived as the ultimate obligation of honour, an extension of the obligations of defending the land and house of the agnatic family and lineage, for all Afghans including non-Pashtun ethric groups.

This growing sense of Afghan nationalism is mainly an effect of the war. Before the invasion, feelings of nationalism were weak in the provinces of Afghanistan, in relation to the sense of ethnic distinction and local and regional interests. The Pashtun especially, with their emphasis on equality and fanily autonomy, have had extreme difficulties in organisation and co-operation in the resistance. The split and division among the Afghans has been a serious problem for the organisation of the resistance, and still is. On the other hand, the sense of unity in jihad, as well as the sense of a common fate as refugees, seem to have grown out of the years of war. As an old refugee woman said in reply to a question concerning the special problems of the refugee women: 'What does it matter, women or man, Pashtun or Tajik - we are all Afghans, and we are all fighting the same war.'

Purdah and control of women

In the refugee situation where the family is 
(al though, in their own eyes, temporarily) deprived of the control of land, the control of the family's house and women seems to have assumed an even more important role than at home, in the symbolic expression of family identity and honour. It could thus be argued that the stricter practice of purdah among the refugees has two functions: protection and defence of the fanily in an environment which is experienced as more alien and dangerous than at home; and the symbolic demonstration of the agnatic family's social and ethnic identity, in a situation where the male Pashtun are deprived of their 'normal' means of demonstrating identity and social status, through economic and social autonomy.

Considering this multifunctional characteristic of purdah, it might be concluded that not only is the practice of purdah not always positively related to, or convergent with interests in landed property (Boesen, 1977), but it may even function as a 'compensation' for the loss of land in the symbolic maintenance of honour and status of the family.

\section{The Tuture}

Despite the examples of flexibility and 'adaptability' of Pashtunwall described here, it must not be forgotten that 1t largely depends on the duration of the war and exile whether the central elements of Pashtunwali will be maintained among the Pashtun refugees. Dependency and passivity are central problems and their demoralising effects are strongly felt, particularly by the old generation, who are left in the camps to look after the families, the men too old to fight or to embark on an economic activity. The only thing to do is to wait and hope that one will be able to see Afghanistan once again in this life, but, as the Afghans say, 'it is all in the hands of God'.

Crucial to the future of Pashtun culture and of Afghanistan are the opportunities offered to the young generation, of education, training, and work, learning skills that are useful in exile as well as in Afghanistan in the event of repatriation, and gaining and keeping self-respect and their sense of identity as Pashtun and Afghans. 
Noters

1. The uncertainty is due to the mobility of the Afghan refugees in Pakistan, and to gaps and double-regiatration in the registration system.

2. Cf. the phrasing of honour as the family's 'symbolic patrimony', in relation to another tribal Middle Bastern society, the Berber in North Africa (P. Bourdieu, 1977: 40ff).

3. This was not frequent among the Pashtun of eastern Afghanistan, according to field material from Kunar, 1977-78; but it is reported concerning the Swat Pashtun in northern Pakistan by Lindholm \& Lindholm, 1979.

4. Cf. Rosen, 1978 and 1984, regarding male-ferale relations in Morocco.

5. The author of the article spent 20 months in Peshawar and in various refugee camps in the NWFP, in connection with a relief programme for Afghan refugee women (Danish Refugee Council).

\section{References}

Boesen, I.W. (1977) 'Purdah og Magt. En komparativ analyse af kvindens situation i den islaniske mellemostlige verden' ('Purdah and Power. A Comparative Analysis of Women's Situation in the Muslin Middle East') Thesis (magisterkonferens), Danish, University of Copenhagen

- (1981) 'Women, Honour, and Love' Folk, vol. 2122, Copenhagen

(1982) 'Conflicts of Interests in Pakhtun Women's Lives', Conference paper, Bielefeld, published 1n: 'Forschungen in und uber Afghanistan', Breckle \& Naumann (eds.), Mitteilungen in des Deutschen Orient-Inst1tuts, no. 22, Hamburg (1983) 'Conflicts of Solidarity in Pakhtun Women's Lives'. In 'Women in Islamic Societies', Studies on Asian Topics no. 6, Scandinavian Institute of Asian Studies, Bo Utas (ed.), Copenhagen

- (1985) From Autonomy to Dependency: Aspects of the "Dependency Symdrome" among Afghan Refugees, in Migration Today, vol. XII, no. 5, New York

- (1985) 'Vi er alle afghanere, og vi kaemper alle 
den samme kamp' ('We are all Afghans, and we are all fighting the same War'), Danish, in Jordens Folk, vol. 20, no. 3, Copenhagen

Bourdieu, P. (1977) Outline of a Theory of Practice, Cambridge Studies in Social Anthropology, Cambridge

Christensen, A. (1980) 'The Pashtun of Kunar: Tribe, Class and Comnunity Organization', in Afghanistan Journal, vol. 7, no. 3, Graz

- $: \overline{(1984)}$ ' When Musiim Identity has Different Meanings: Religion and Politics in Contemporary Afghanistan' paper prepared for Symposium on Islam: State and Society, University of Arhus, Denmark

Janata, A and Hassas, R. (1975) 'Ghairatman - Der gute Pashtune. Exkurs uber die Grundlagen des Pashtunwali', Afghanistan Journal, vol. 2, 3, Graz

Lindholm, C. and Lindholm, C. (1979) 'Marriage as Warfare', Natural History, Oct. 1979

Papanek, H. (1973) 'Purdah: separate worlds and symbolic shelter', in: Comparative Studies of Social History, 15

Pastner, C. Mc.Cl. (1972) 'A Social Structural and Historical Analysis of Honor, Shame, and Purdah', Anthropological Quarterly, 45, 4

Rosen, L. (1978) 'The Negotiation of Reality', in Women in the Muslim World, L. Beck and N. Keddie (eds.), Harvard Univeraity Press

- (1984) Bargaining for Reality, Chlcago 